This document is published in:

Journal of Industrial Economics (2003), 51(1), 77-91.

DOI: 10.1111/1467-6451.00192

(C) 2003 Blackwell Publishers Ltd. 


\title{
AN EMPIRICAL EVALUATION OF THE DETERMINANTS OF RESEARCH JOINT VENTURE FORMATION*
}

\author{
Roberto Hernán,† Pedro L. Marínł and Georges Siotis§
}

This paper empirically analyses the determinants of firm participation in Research Joint Ventures (RJVs). A review of the theoretical literature highlights the difficulty of identifying testable hypotheses. Using a large database of European RJVs, we estimate a participation equation at the firm level using the logit procedure. We find that sectorial R\&D intensity, industry concentration, firm size, technological spillovers, and past RJV participation positively influence the probability of forming RJVs. By contrast, patents' effectiveness reduce the likelihood of RJV formation. Last, country fixed effects suggest that firms from larger countries are less likely to participate in cross-border RJVs.

\section{INTRODUCTION}

Research Joint Ventures (RJVs) are agreements whereby firms decide to share technological knowledge while, in principle, continuing to compete against each other in the product market. The aim of this paper is empirically to identify the firm and industry characteristics that determine RJV formation.

Recent theoretical contributions have highlighted the complex mechanisms that underlie RJV participation. First, RJVs involve the internalisation of technological spillovers and R\&D cost-sharing, as well as the assimilation of knowledge that may be of strategic importance (Kamien, Müller and Zang [1992]). Second, the degree of size-related asymmetries between firms influences participation decisions (Petit and

\footnotetext{
* We are particularly grateful to Bruno Casiman, Jordi Jaumandreu, Praveen Kujal and the editor, who provided many thoughtful comments. This paper is part of the STEP TO RJV project, funded by the TSER programme of the European Commission, whose financial support is gratefully acknowledged. The project was coordinated by Yannis Caloghirou, Ass. Professor at the NTUA and undertaken by a consortium of seven research groups, namely: LIEE/NTUA (Greece), FEEM (Italy), IDATE (France), PREST (UK), SIRN (UK), SSE (Sweden) and Universidad Carlos III de Madrid (Spain).

† Authors' affiliations: Universidad Carlos III de Madrid, Departamento de Economía, Calle Madrid 126, 28903-Getafe, Spain.

email:rhernan@eco.uc3m.es

+Universidad Carlos III de Madrid, Departamento de Economía, Calle Madrid 126, 28903-Getafe, Spain and CEPR. email:marin@eco.uc3m.es

$\S$ Universidad Carlos III de Madrid, Departamento de Economía, Calle Madrid 126, 28903-Getafe, Spain.

email: siotis@eco.uc3m.es
} 
Towlinsky [1999]). Third, the research paths (complementary versus substitute R\&D) affect the incentives to form an RJV (Katsoulacos and Ulph [1998]). Finally, all these models show that strategic interactions in the product market affect the decision to participate in RJVs. This effect may be direct (depending on the degree of product market complementarity) or indirect (e.g. when RJVs are simply used as a vehicle to enhance the feasibility of product market collusion). ${ }^{1}$

The business literature provides additional and useful information regarding RJV formation. It stresses that firms have different 'absorptive capacities' of research results, which in turn determine their willingness to form RJVs. The absorptive capacity of each firm is determined by factors such as size, past experience with research cooperation, corporate culture and business line of activity (Kogut [1991]).

Last, specific public policies towards RJVs have been developed. On the one side, competition law determines the nature of inter-firm cooperation that is legally accepted. On the other side, subsidies are sometimes granted to encourage RJV creation, as these arrangements are believed to have some socially beneficial characteristics, such as the reduction in the duplication of $R \& D$ costs.

Given the complexity of the problem, empirical research has been hampered by a two-fold constraint: lack of micro data, and the unobservability of a number of key parameters highlighted by theoretical models, such as the level of technological spillovers or differences in absorptive capacity across firms. As a result, the empirical literature using a structural approach is scarce. To the best of our knowledge, the only contribution that overcomes some of these problems is that of Röller, Tombak and Siebert [1998]. They develop a duopoly model that contains four ingredients: spillovers, $R \& D$ cost sharing, firm asymmetries and product market complementarities. They show that size symmetry and product complementarity between firms enhance the likelihood of RJV formation. Note that their analysis focuses on the formation of pairs between firms that are known to have created an RJV. Thus, the question they ask is: given that a firm has decided positively on participation, which partners does it choose? However, they do not address the issue of which firms are more likely to decide on embarking in an RJV in the first place.

In this paper we attempt to fill the gap between theory and empirical testing by making use of a large firm level data-set. The data pertains to RJVs formed under the umbrella of the Eureka and EU Framework

\footnotetext{
${ }^{1}$ Both in Europe and the US, the legal framework applicable to RJVs recognises that these agreements might be used as a vehicle for collusion. For instance, in EU law, a distinction is established between 'concentrative' and 'cooperative' joint ventures. See Neven, Papandropoulos and Seabright [1998] for a thorough economic and legal analysis.
} 
Programmes, both pan-European initiatives aimed at enhancing inter-firm research cooperation. As a control group, we consider a much larger sample of firms that could potentially participate in these RJVs. Thus, we are able to measure the effect of the relevant firm and industry characteristics that influence RJV formation. We use the logit estimation procedure as we can observe if the firms under analysis decide or not to form an RJV in a given period, but not their profits under these two alternative scenarios.

We find that sectorial R\&D intensity, industry concentration, firm size, technological spillovers, and past RJV participation positively influence the probability of forming RJVs. By contrast, patents' effectiveness reduce the likelihood of RJV formation. Last, country fixed effects suggest that firms from larger countries are less likely to participate in cross-border RJVs.

The remainder of the paper is organised as follows. Section II describes the data and how the variables are constructed and presents the empirical specification, while Section III presents the econometric results.

\section{DATA, VARIABLE CONSTRUCTION AND ECONOMETRIC SPECIFICATION}

\section{II(i). The Data}

The set of RJVs which are analysed in this paper are retrieved from the 'STEP to RJV' database, constructed as part of an EU financed TSER project. These RJVs have been formed under the umbrella of either the Eureka Programme or the EU Framework Programme for Science and Technology (EU-FP in the remainder of the paper). Eureka was launched in the mid-eighties as a pan-European initiative aimed at enhancing cross-border technological cooperation. Obtaining the Eureka label does not entitle firms to EU subsidies, nor is Eureka an EU programme. However, obtaining the Eureka 'seal of approval' enhances firms' ability to receive subsidies from their respective national authorities. RJVs formed under EU-FP programmes are eligible for a subsidy, which varies according to the nature of the project. Information on these projects has been retrieved from CORDIS (an EU database which centralises information on all EU financed projects in a raw format), and the Eureka web page. Both programmes require participants to establish transnational projects (i.e. RJVs involving firms from only one country are not eligible).

Our data set is constructed using three separate sources. First, we use data on individual Eureka and EU-FP RJVs. In both cases, we have a brief description of the project, a sectorial acronym, and the name of the participating firms. Some projects were launched in the mid eighties, but 
the bulk of them were initiated in the nineties. We have data on RJVs until $1996 .^{2}$

Table I depicts the total number of projects involving a firm from a given country, the geographical origin of firms participating in RJVs, and the average number and percentage of firms of the same nationality participating in a given project. The data pertains to projects covering the period 1986-1996.

There is a high correlation between number of projects, average number and percentage of participants of the same nationality, and country size. This should come as no surprise; nonetheless, some interesting patterns emerge. For instance, while German and French firms appear keen to participate in EU-FP projects, many of these cooperations involve compatriot firms. This tendency is even more marked for Eureka, since the figure is larger for Eureka than EU-FP for almost all countries. This may be taken as an indication that despite the programmes' declared objective of fostering pan-European cooperation, many of the projects are still predominantly national. Firms of non-EU origin tend to be keener to participate in Eureka. This is the case of Norway, Switzerland, Poland, Sweden, and Finland (the latter two countries were still not part of the EU). Last, the average size of EU-FP projects is larger ( 7.15 firms per project) compared to Eureka projects (5.89 firms).

Throughout the construction of the sample, we used a four-digit sectorial breakdown. It would have been preferable to work at eight digits, but some of the data were not available at such a fine level of aggregation. The nomenclature used is that of the British Central Statistical Office (CSO).

A word is in order on the composition of these RJVs. While some RJVs in our sample are clearly vertical (involving business units in different sectors), most of them involve at least two firms operating in the same market segment. Table II provides the sectorial affiliation of participating firms. As can be readily seen, firms belonging to the information technology and aerospace clusters represent the most important contingent. This is followed by environmental and energy technologies.

Table III provides information on the number of participants by project. In the case of EU-FP projects, the distribution is fairly even, with a peak for projects containing four to seven participants. By contrast, Eureka projects involve, on average, fewer participants.

\footnotetext{
${ }^{2}$ Our data does not contain all European RJVs, as some of them may take place outside the framework of the EU-FP or Eureka. We are nonetheless confident that our sample contains the bulk of cross-border RJVs. The reason is the following: once the costs of establishing a cross-border cooperation have been incurred, the additional outlays associated with gaining an EU subsidy, or the Eureka seal, are minimal. By contrast, the gains are important, as they may involve substantial subsidies.
} 
TABLE I

RJV PARTICIPATION BY COUNTRY

\begin{tabular}{|c|c|c|c|c|c|c|c|c|c|c|c|c|}
\hline \multirow[b]{3}{*}{ Country } & \multicolumn{6}{|c|}{ EU Framework Programme } & \multicolumn{6}{|c|}{ Eureka } \\
\hline & \multicolumn{2}{|c|}{ Projects } & \multicolumn{2}{|c|}{ Firms } & \multirow{2}{*}{$\begin{array}{l}\text { Average no. of } \\
\text { local firms per } \\
\text { project }^{\mathrm{a}}\end{array}$} & \multirow{2}{*}{$\begin{array}{l}\% \text { of local } \\
\text { firms per } \\
\text { project }^{c}\end{array}$} & \multicolumn{2}{|c|}{ Projects } & \multicolumn{2}{|c|}{ Firms } & \multirow{2}{*}{$\begin{array}{l}\text { Average no. of } \\
\text { local firms per } \\
\text { project }^{\mathrm{a}}\end{array}$} & \multirow{2}{*}{$\begin{array}{l}\% \text { of local } \\
\text { firms per } \\
\text { project }^{\mathrm{c}}\end{array}$} \\
\hline & No. & $\%$ & No. & $\%$ & & & No. & $\%$ & No. & $\%$ & & \\
\hline Austria & 264 & 6.8 & 167 & 1.7 & 1.25 & 22.2 & 122 & 11.8 & 154 & 3.7 & 1.80 & 29.9 \\
\hline Belgium & 872 & 22.5 & 482 & 4.9 & 1.48 & 22.9 & 127 & 12.3 & 141 & 3.4 & 1.47 & 28.2 \\
\hline Czech Republic & 5 & 0.1 & 5 & 0.1 & 1.00 & - & 24 & 2.3 & 27 & 0.7 & 1.58 & 29.4 \\
\hline Denmark & 632 & 16.3 & 335 & 3.4 & 1.43 & 23.9 & 129 & 12.5 & 128 & 3.1 & 1.49 & 34.5 \\
\hline Finland & 393 & 10.1 & 190 & 1.9 & 1.35 & 18.7 & 120 & 11.7 & 160 & 3.9 & 2.15 & 37.1 \\
\hline France & 2,196 & 56.7 & 1,490 & 15.3 & 2.05 & 26.5 & 362 & 35.1 & 653 & 15.8 & 2.82 & 38.2 \\
\hline Germany & 2,313 & 59.7 & 1,695 & 17.4 & 2.02 & 27.1 & 364 & 35.3 & 604 & 14.6 & 2.54 & 35.9 \\
\hline Greece & 840 & 21.7 & 367 & 3.8 & 1.49 & 23.6 & 33 & 3.2 & 38 & 0.9 & 1.76 & 20.8 \\
\hline Hungary & 9 & 0.2 & 9 & 0.1 & 1.22 & 3.5 & 38 & 3.7 & 41 & 1.0 & 1.47 & 28.4 \\
\hline Iceland & 19 & 0.5 & 20 & 0.2 & 1.47 & 17.5 & 9 & 0.9 & 19 & 0.5 & 2.22 & 28.2 \\
\hline Ireland & 487 & 12.6 & 207 & 2.1 & 1.27 & 21.3 & 18 & 1.7 & 17 & 0.4 & 1.06 & 0.6 \\
\hline Italy & 1,653 & 42.7 & 1,025 & 10.5 & 1.78 & 26.6 & 186 & 18.1 & 279 & 6.7 & 2.32 & 30.0 \\
\hline Luxembourg & 37 & 1.0 & 28 & 0.3 & 1.11 & 19.5 & 8 & 0.8 & 10 & 0.2 & 1.25 & 22.9 \\
\hline Netherlands & 1,217 & 31.4 & 631 & 6.5 & 1.54 & 20.8 & 276 & 26.8 & 366 & 8.8 & 1.82 & 36.7 \\
\hline Norway & 288 & 7.4 & 155 & 1.6 & 1.33 & 19.0 & 130 & 12.6 & 176 & 4.3 & 2.02 & 37.7 \\
\hline Poland & 12 & 0.3 & 15 & 0.2 & 1.33 & 10.9 & 17 & 1.7 & 23 & 0.6 & 1.65 & 27.4 \\
\hline Portugal & 558 & 14.4 & 292 & 3.0 & 1.38 & 22.3 & 64 & 6.2 & 80 & 1.9 & 1.91 & 38.9 \\
\hline Spain & 1,170 & 30.2 & 773 & 7.9 & 1.61 & 27.5 & 218 & 21.2 & 307 & 7.4 & 1.84 & 38.2 \\
\hline Sweden & 656 & 16.9 & 313 & 3.2 & 1.38 & 17.8 & 179 & 17.4 & 206 & 5.0 & 1.53 & 25.4 \\
\hline Switzerland & 373 & 9.6 & 165 & 1.7 & 1.23 & 14.4 & 173 & 16.8 & 261 & 6.3 & 2.43 & 43.1 \\
\hline United Kingdom & 2,315 & 59.8 & 1,381 & 14.2 & 1.85 & 25.5 & 261 & 25.3 & 448 & 10.8 & 2.39 & 36.6 \\
\hline Europe & 3,874 & 100.0 & 9,745 & 100.0 & $7.15^{\mathrm{b}}$ & 99.7 & 1,030 & 100.0 & 4,138 & 100.0 & 5.89 & 96.7 \\
\hline
\end{tabular}

Note: ${ }^{\text {a }}$ This average figure is computed for projects where at least one firm from this country is involved.

${ }^{\mathrm{b}}$ In this case, local means European. Accordingly, this figure represents average number of firms per project.

${ }^{\mathrm{c}}$ This percentage is defined as the mean value of the percentage of other partners in each project that are from the same country. 
TABLE II

Distribution of Projects by Technological Area

\begin{tabular}{lcr}
\hline Technological area & No. of RJVs & $\%$ \\
\hline Information & 1,229 & 26 \\
Aerospace & 892 & 19 \\
Energy & 511 & 11 \\
Environment & 436 & 9 \\
Agriculture & 387 & 8 \\
Education/Training & 282 & 6 \\
Medical and Biotechnology & 263 & 6 \\
Robotics/Production automation & 172 & 4 \\
Measurement methods & 142 & 3 \\
Transport & 141 & 3 \\
Electronics/Microelectronics & 118 & 2 \\
New materials & 112 & 2 \\
Communications & 43 & 1 \\
Lasers & 26 & 1 \\
Total & 4,754 & 100 \\
\hline
\end{tabular}

TABLE III

Distribution of Projects by Number of Participants

\begin{tabular}{|c|c|c|c|c|c|c|}
\hline \multirow{2}{*}{$\frac{\text { No. of participants }}{3 \text { or less }}$} & \multicolumn{2}{|c|}{$\begin{array}{l}\text { EU Framework } \\
\text { Programme }\end{array}$} & \multicolumn{2}{|c|}{ Eureka } & \multicolumn{2}{|c|}{ Total } \\
\hline & 546 & $14 \%$ & 439 & $43 \%$ & 985 & $20 \%$ \\
\hline 4 or 5 & 1,048 & $27 \%$ & 249 & $24 \%$ & 1,297 & $26 \%$ \\
\hline 6 or 7 & 977 & $25 \%$ & 151 & $15 \%$ & 1,128 & $23 \%$ \\
\hline 8 to 10 & 732 & $19 \%$ & 78 & $8 \%$ & 810 & $17 \%$ \\
\hline 11 to 15 & 391 & $10 \%$ & 64 & $6 \%$ & 455 & $9 \%$ \\
\hline 16 or more & 180 & $5 \%$ & 50 & $5 \%$ & 230 & $5 \%$ \\
\hline Total & 3,874 & $100 \%$ & 1,031 & $100 \%$ & 4,905 & $100 \%$ \\
\hline
\end{tabular}

The second source of information pertains to participating firms. We retrieved this data from Amadeus, a database produced by Bureau Van Dijk, a specialist provider of firm-level data based on balance sheet information. In the version of the database that we used, the total number of entries exceeds 200,000 firms, with detailed information on ownership structure, and a fine sectorial affiliation (up to 8 digits). Geographical coverage pertains to Europe (including Central and Eastern Europe). To our knowledge, Amadeus is the most comprehensive source of firm level data in Europe. Since its launch, this database has been used quite extensively in academic circles (see for instance, Filer and Hanousek [2002] for an overview, or Bureau van Dijk's web page, www.bvdny.com).

We retrieved the relevant information on firms that appear both in Amadeus and in our RJV database, and dropped firms which had formed EU-FP or Eureka RJVs, but for which no data was available in Amadeus. 
We retrieved unconsolidated balance sheets in order to make use of data pertaining to the relevant business establishment. We have been extremely careful in identifying the relevant business unit, as many conglomerates participate in these RJVs. ${ }^{3}$

Given that information on business units and industry characteristics only span the period 1991-1996, and that some of the independent variables may be endogenous to the model, we construct our dependent variable for the period $1995-96 .{ }^{4}$ This allows us to deal with possible issues of endogeneity by using lagged values for the independent variables (i.e. pre-1995 values). The sample of firms that had formed an EU-FP or Eureka RJV during the period 1995-1996 yields a total of 1222 observations. We could gather the relevant firm and industry level variables for 798 of them, and thus dropped the remaining 424 observations.

As mentioned above, it is necessary to form a control group with firms that have not joined an RJV during the period under study. We assume that Amadeus is a fair representation of the true universe, and use the entire Amadeus database as a control group. In some cases, entries in Amadeus are incomplete, and variables are sometimes missing (e.g., number of employees). The sample for which we could gather all the relevant information yields a total of 54610 observations (of which 798 have formed one or more EU-FP or Eureka RJV during the period 1995-96).

The third source of information we use is the Worldscope database. The latter provides $R \& D$ expenditures for about 1500 large firms. The data is available for the period 1991-1996 at the SIC four digit level of aggregation, which we converted into their CSO equivalent using detailed conversion tables. This allowed us to construct $R \& D$ intensity at the four digit level.

\section{II(ii). Variables and Econometric Specification}

We need to construct a set of variables that measure or proxy the determinants of RJV formation identified in the theoretical models, and explicitly spell out testable hypotheses. More precisely, we need measures pertaining to firm size, concentration, industry R\&D intensity, and industry specific proxies for the extent of spillovers and the effectiveness of intellectual property rights protection. In addition, for some firms, willingness to join an RJV may be influenced by past experience with RJVs. This may reflect the success or failure of past ventures, the existence

\footnotetext{
${ }^{3}$ The presence of large, multi-product firms, poses a problem. Suppose that ABB participates in an RJV in semi-conductors. The relevant business units are the ABB subsidiaries that appear with this product as their main business line at the four-digit level. The consolidated, worldwide accounts of the ABB group would be inappropriate here.

${ }^{4}$ Throughout the remainder of the text, one period refers to two years.
} 
of once-for-all fixed costs associated with RJV formation, as well as a learning process in achieving successful cooperation. Last, the origin of firms may introduce a country specific effect. Indeed, it seems that national idiosyncracies influence the attitude of firms towards formal cooperation (Nelson [1993]).

To construct the variables, we take four digit sectors and Europe as representing the relevant market. The variables that we include in the regressions are as follows:

To control for differences in the extent and magnitude of potential cost reductions across industries, we include $\mathrm{R} \& \mathrm{D}$ intensity at the level of the industry, calculated as total R\&D expenditures over total sales, reported by firms belonging to that four-digit sector. We retrieved this data from Worldscope, and we call this variable $R D I$. All else equal, costs reductions resulting from a successful RJV will be more important in R\&D intensive industries, thus affecting firms' incentives to join in the first place. This cost reduction effects should positively influence firms' willingness to form an RJV.

To measure differences in the importance of spillovers across industries, we constructed two proxies. The first is based on data taken from Mansfield [1985] which measures the speed at which innovations - unwillingly — diffuse within an industry. It refers to both product and process innovation and is measured as the average number of months before the diffusion of an innovation in the industry. The information is available at two to four digits, depending on the industry. We assigned values for this variable accordingly (for instance, in some sectors, we have a perfect correspondence; in others, we assigned the value associated to the higher level of aggregation for which the spillover variable was available). This variable acts as a proxy for the 'spillover lag', and we label it SPL. Another concurrent interpretation pertaining to this variable is that it reflects the importance of lead time in R\&D intensive industries. We expect this variable to appear with a negative sign, since a slow diffusion of innovations within an industry is indicative of limited spillovers. The drawback is that data is only available for industries that undertake R\&D on a significant scale. Our sample also contains firms belonging to sectors not included in Mansfield's sample. For the sectors for which no data is available, we have assigned the average value of the spillover lag variable. ${ }^{5}$

\footnotetext{
${ }^{5}$ We also estimated our equations excluding the industries for which no data is available, and the value and significance of the coefficient associated to SPL barely changed. With the entire sample, we also included a dummy equal to one for industries for which no spillover information is available, and zero otherwise. The dummy proved not significant, and the other coefficients were not affected by this inclusion. Last, we estimated our regressions excluding $S P L$ and the results remained identical for the remaining variables. All of the above indicates that our results are not driven by this coding choice. See the Journal's website for these regressions.
} 
The second proxy is built using the data reported by Levin, Klevorick, Nelson and Winter [1987] that measures the effectiveness of patents in eighteen industrial sectors (both product and process). We expect 'patent effectiveness' (denoted $P A T E F$ ) to appear with a negative sign, as firms that operate in sectors where patents are effective do not need to rely on RJVs in order to internalise spillovers. Effective patents ensure that innovators can successfully protect their intellectual property rights, thus driving unintended leakages (spillovers) to zero. As is the case with the data reported by Mansfield [1985], there are some sectors for which this particular variable is not available. We adopted the strategy described above, and assigned the average value of this variable to sectors for which data is missing. ${ }^{6}$ Note that, while both these proxies (SPL and PATEF) are related to spillovers, the original sources of information are quite distinct.

In the case of an asymmetric oligopoly, internalisation of spillovers via RJV formation is greater the smaller the number of rivals in that industry segment. In order to measure market concentration, we constructed the Hirschman-Herfindähl index $(H H I)$ for each four-digit sector present in our sample. The value taken by the $H H I$ is the average for the 1991-94 period. Note that this variable also generates information as to whether firms join RJVs to reduce the toughness of actual or potential competition. Both the spillover and market power motives predict a positive coefficient on this variable.

To represent asymmetries across firms, we introduce a measure of firm size, namely the natural logarithm of the number of employees for each firm in our sample, that we denote $\log (F S)$. This measure is fairly stable over time. We have taken firm level averages for the 1991-94 period. According to most oligopoly models for homogeneous products, size differences within an industry reflect differential efficiency. ${ }^{7}$ Also, if there are fixed costs associated with forming RJVs (such as paper work and/or the establishment of specific facilities), large firms may be more willing to join, as they can spread these costs across a larger volume of sales. In addition, size is likely to be highly correlated with 'absorptive capacity', thus increasing the likelihood to join. Last, it may be the case that size may influence the public authority responsible for these programmes. This may possibly result from exogenous preferences 'for' or 'against' big business, or a process of regulatory capture. An alternative measure of

\footnotetext{
${ }^{6}$ The comment made in the previous footnote regarding $S P L$ also apply for $P A T E F$, i.e. the results are not sensitive to this coding choice.

${ }^{7}$ Most RJV models represent competition in the third stage of the game as quantity Cournot competition. One of the basic results of the Cournot model is that firms' market share within the industry is inversely related to their marginal costs, i.e. directly related to their efficiency.
} 
asymmetries is market share (denoted $M S$ ), calculated as firm over industry size, both measured by the number of employees.

Practitioners and the business literature stress that some firms are keener to cooperate than others as a result of differences such as corporate culture. It is also stressed that experience or past participation in RJVs may make it easier to repeat the experience (with the same group of firms, or new partners). We have thus constructed 'quantitative' variables that take into account the cumulated number of past participations in Eureka and the EU Framework Programme for the period 1986-92, and label these variables $E X P-F P$ and $E X P-E U$. These variables also provides information on the success of these programmes (in terms of firms' willingness to take part in them). We also include a set of dummies for the country of origin of the firm. The data will itself reveal whether geographic origin is an important determinant behind the decision to form a project.

Last, the dependent variable takes value 1 if the business unit has participated in at least one EU-FP or Eureka RJV initiated during the period 1995-96, and 0 otherwise. Table IV reports the descriptive statistics for all the variables that we used in the estimation.

The expression to be estimated can be written as:

$$
\begin{aligned}
\operatorname{Pr}\left(R J V_{i, j, t}=\right. & 1)=F\left(\beta_{0}+\beta_{1} R D I_{j, t-2}+\beta_{2} S P L_{j}+\beta_{3} P A T E F_{j}\right. \\
& +\beta_{4} H H I_{j, t-2}+\beta_{5} \log (F S)_{i, t-2}+\beta_{6} M S_{i, t-2} \\
& \left.+\beta_{7} E X P-F P_{i, t-2}+\beta_{8} E X P-E U_{i, t-2}+\sum_{k=1}^{K} \gamma_{k} \text { Country }_{k, i}\right)
\end{aligned}
$$

where $F($.$) is the logistic cumulative distributive function. The sub-indices$ $i, j, t$ and $k$, respectively denote firm, sector, time, and country. We have lagged our independent variables by two periods in order to mitigate the endogeneity problem from our estimation. Since the residuals are likely to be correlated within the industries, and especially given the industry level

TABLE IV

Descriptive Statistics

\begin{tabular}{lcccc}
\hline Variables & Mean & Std. Dev. & Min. & Max. \\
\hline Prob $\left(\mathrm{RJV}_{i}\right)$ & & & 0 & 1 \\
R\&D Intensity $_{j}$ & 0.02 & 0.02 & 0.0000125 & 0.1044 \\
Spillover lag $_{j}$ & 12.57 & 1.06 & 7.815 & 16.545 \\
Patents effectiveness $_{j}$ & 3.95 & 0.30 & 2.95 & 5.70 \\
HHI $_{j}$ & 0.03 & 0.05 & 0.003 & 0.678 \\
Firm size $_{i}$ & 321 & 2231 & 1 & 229161 \\
Market Share $_{i}$ & 0.003 & 0.01 & $1.4^{*} 10^{-6}$ & 0.817 \\
Experience $_{i, \text { EU-FP }}$ & 0.03 & 0.64 & 0 & 62 \\
Experience $_{i, \text { Eureka }}$ & 0.01 & 0.19 & 0 & 13 \\
\hline
\end{tabular}


variables (Moulton [1990]), our calculation of standard errors controls for this correlation by clustering at the four-digit level.

\section{ECONOMETRIC RESULTS}

Table $\mathrm{V}$ presents the results of estimating alternative specifications for expression (1) using the logit estimation technique and controlling for residual correlation among observations from the same industry. The estimation contains industry variables ( $R \& D$ intensity, the spillover lag and concentration), and firms specific variables (size and past participation in Eureka and EU-FP projects). In Table V, we present the results pertaining to six distinct specifications. The purpose of this exercise is to assess whether the results are sensitive to the exclusion or inclusion of specific variables. Last, in some regressions we include country dummies whose point estimates are presented in Table VI. The Netherlands were chosen as the reference country.

TABLE V

Econometric Results. Dependent Variable: $\operatorname{Prob}\left(\mathrm{RJV}_{t}=1\right)$

\begin{tabular}{|c|c|c|c|c|c|c|}
\hline Variables & (1) & (2) & (3) & (4) & (5) & (6) \\
\hline Constant & $\begin{array}{r}-5.57 \\
(6.98)\end{array}$ & $\begin{array}{l}-5.58 \\
(7.07)\end{array}$ & $\begin{array}{c}-1.23 \\
(1.50)\end{array}$ & $\begin{array}{c}-5.03 \\
(6.76)\end{array}$ & $\begin{array}{r}-5.65 \\
(6.53)\end{array}$ & $\begin{array}{r}-5.02 \\
(6.44)\end{array}$ \\
\hline R\&D Intensity ${ }_{j}$ & $\begin{array}{l}17.43 \\
(6.12)\end{array}$ & $\begin{array}{l}17.42 \\
(6.15)\end{array}$ & $\begin{array}{l}22.94 \\
(7.48)\end{array}$ & $\begin{array}{l}13.33 \\
(5.28)\end{array}$ & $\begin{array}{l}17.80 \\
(6.22)\end{array}$ & $\begin{array}{l}14.08 \\
(5.62)\end{array}$ \\
\hline Spillover $\operatorname{lag}_{j}$ & $\begin{array}{c}-0.14 \\
(2.24)\end{array}$ & $\begin{array}{c}-0.14 \\
(2.24)\end{array}$ & $\begin{array}{r}-0.18 \\
(2.65)\end{array}$ & $\begin{array}{c}-0.16 \\
(2.73)\end{array}$ & $\begin{array}{c}-0.13 \\
(2.16)\end{array}$ & $\begin{array}{r}-0.15 \\
(2.67)\end{array}$ \\
\hline $\begin{array}{l}\text { Patents } \\
\quad \text { effectiveness }{ }_{j}\end{array}$ & $\begin{array}{c}-0.36 \\
(2.70)\end{array}$ & $\begin{array}{c}-0.36 \\
(2.68)\end{array}$ & $\begin{array}{c}-0.42 \\
(3.43)\end{array}$ & $\begin{array}{c}-0.21 \\
(1.65)\end{array}$ & $\begin{array}{c}-0.36 \\
(2.39)\end{array}$ & $\begin{array}{c}-0.20 \\
(1.47)\end{array}$ \\
\hline $\mathrm{HHI}_{j}$ & $\begin{array}{c}2.40 \\
(1.64)\end{array}$ & $\begin{array}{l}2.41 \\
(1.69)\end{array}$ & $\begin{array}{c}3.09 \\
(1.98)\end{array}$ & $\begin{array}{l}2.08 \\
(1.55)\end{array}$ & $\begin{array}{c}2.37 \\
(1.73)\end{array}$ & $\begin{array}{c}2.07 \\
(1.58)\end{array}$ \\
\hline $\log (\text { Firm size })_{i}$ & $\begin{array}{c}0.73 \\
(18.09)\end{array}$ & $\begin{array}{c}0.74 \\
(20.17)\end{array}$ & & $\begin{array}{c}0.54 \\
(14.41)\end{array}$ & $\begin{array}{c}0.81 \\
(19.15)\end{array}$ & $\begin{array}{c}0.61 \\
(14.23)\end{array}$ \\
\hline Market Share $_{i}$ & $\begin{array}{c}0.09 \\
(0.07)\end{array}$ & & $\begin{array}{l}15.16 \\
(6.58)\end{array}$ & & & \\
\hline Experience $_{i, \text { EU-FP }}$ & & & & $\begin{array}{c}2.04 \\
(12.50)\end{array}$ & & $\begin{array}{c}1.96 \\
(12.31)\end{array}$ \\
\hline Experience $_{i, \text { Eureka }}$ & & & & $\begin{array}{c}0.81 \\
(6.10)\end{array}$ & & $\begin{array}{c}0.75 \\
(5.56)\end{array}$ \\
\hline Country dummies & NO & NO & NO & NO & YES & YES \\
\hline $\begin{array}{l}\text { Pseudo } R^{2} \\
\text { Wald } \chi^{2} \text { (d.f.) }\end{array}$ & $\begin{array}{c}0.19 \\
526.99(6)\end{array}$ & $\begin{array}{c}0.19 \\
526.42(5)\end{array}$ & $\begin{array}{c}0.10 \\
163.46(5)\end{array}$ & $\begin{array}{c}0.32 \\
526.45(7)\end{array}$ & $\begin{array}{c}0.22 \\
831.28(23)\end{array}$ & $\begin{array}{c}0.34 \\
801.86(25)\end{array}$ \\
\hline $\begin{array}{l}\text { Number of } \\
\text { observations }\end{array}$ & 54610 & 54610 & 54610 & 54610 & 54188 & 54188 \\
\hline
\end{tabular}

Note: $t$-statistics in absolute values in parentheses. 
TABLE VI

Country Dummies Coefficient Estimates

\begin{tabular}{|c|c|c|}
\hline Country dummies & (5) & (6) \\
\hline Austria & $\begin{array}{c}0.12 \\
(0.31)\end{array}$ & $\begin{array}{c}0.27 \\
(0.73)\end{array}$ \\
\hline Belgium & $\begin{array}{c}-0.04 \\
(0.16)\end{array}$ & $\begin{array}{c}-0.21 \\
(0.83)\end{array}$ \\
\hline Switzerland & $\begin{array}{c}-0.08 \\
(0.23)\end{array}$ & $\begin{array}{c}0.17 \\
(0.48)\end{array}$ \\
\hline Germany & $\begin{array}{c}-0.57 \\
(2.13)\end{array}$ & $\begin{array}{c}-0.79 \\
(2.96)\end{array}$ \\
\hline Denmark & $\begin{array}{c}0.57 \\
(2.53)\end{array}$ & $\begin{array}{c}0.26 \\
(1.16)\end{array}$ \\
\hline Spain & $\begin{array}{c}-0.66 \\
(0.93)\end{array}$ & $\begin{array}{c}-1.11 \\
(1.37)\end{array}$ \\
\hline Finland & $\begin{array}{c}0.61 \\
(2.00)\end{array}$ & $\begin{array}{c}0.53 \\
(1.74)\end{array}$ \\
\hline France & $\begin{array}{c}-0.53 \\
(2.01)\end{array}$ & $\begin{array}{c}-0.78 \\
(3.07)\end{array}$ \\
\hline UK & $\begin{array}{c}-0.97 \\
(3.85)\end{array}$ & $\begin{array}{c}-0.85 \\
(3.52)\end{array}$ \\
\hline Greece & $\begin{array}{c}0.65 \\
(2.00)\end{array}$ & $\begin{array}{c}0.36 \\
(1.12)\end{array}$ \\
\hline Ireland & $\begin{array}{c}0.07 \\
(0.13)\end{array}$ & $\begin{array}{c}0.00 \\
(0.00)\end{array}$ \\
\hline Iceland & $\begin{array}{c}0.75 \\
(0.69)\end{array}$ & $\begin{array}{c}0.57 \\
(0.50)\end{array}$ \\
\hline Italy & $\begin{array}{c}-0.54 \\
(1.99)\end{array}$ & $\begin{array}{c}-0.71 \\
(2.92)\end{array}$ \\
\hline Luxembourg & $\begin{array}{c}-0.19 \\
(0.29)\end{array}$ & $\begin{array}{c}-0.30 \\
(0.48)\end{array}$ \\
\hline Norway & $\begin{array}{c}-0.04 \\
(0.10)\end{array}$ & $\begin{array}{c}-0.22 \\
(0.65)\end{array}$ \\
\hline Portugal & $\begin{array}{c}-0.19 \\
(0.58)\end{array}$ & $\begin{array}{c}-0.27 \\
(0.76)\end{array}$ \\
\hline Sweden & $\begin{array}{c}0.05 \\
(0.17)\end{array}$ & $\begin{array}{c}0.10 \\
(0.37)\end{array}$ \\
\hline Poland & $\begin{array}{c}-4.52 \\
(4.57)\end{array}$ & $\begin{array}{c}-3.91 \\
(3.92)\end{array}$ \\
\hline
\end{tabular}

Note: These two columns correspond to regressions (5) and (6) in Table 5. The Netherlands is the omitted country.

$t$-statistics in absolute values in parentheses. 
As expected, sectorial R\&D intensity $(R D I)$ appears with a positive sign, and it is significant at less than the $1 \%$ level. This reflects the fact that an RJV is an attractive option for projects involving large R\&D outlays because of the cost sharing element.

The point estimate associated with the spillover lag $(S P L)$ is also significant at the $1 \%$ or $5 \%$ levels, depending on the specification. This indicates that RJVs are more likely to materialise in sectors where technological knowledge diffuses fast. The variable measuring patent effectiveness (PATEF; also significant at the $1 \%$ or $5 \%$ levels) confirms this finding: when intellectual property rights are successfully protected by patents, firms have less of an incentive to engage in RJVs. As mentioned previously, both variables are related to spillovers, but they each act as proxies for quite distinct economic phenomena. The fact that both are significant serves to emphasise that knowledge diffusion is central to our understanding of RJV formation. ${ }^{8}$

An industry's $H H I$ reflects the degree of concentration, or conversely, the extent of fragmentation. The less fragmented is an industry, the easier it is to identify the appropriate partners to form an RJV. In addition, a more concentrated industry offers greater scope for effective internalisation of spillovers. The coefficient is positive and significant (at the $10 \%$ level or less in most specifications), lending support to the arguments presented above. Note that while the variables $S P L$ and PATEF act as proxies for the presence of spillovers at the industry level, concentration captures the potential for internalising them within an RJV.

The coefficient for the variable measuring firm size $(\log (F S))$ is positive and highly significant (well below the 1\% level). There is a number of (non-exclusive) explanations for this finding. First, it may reflect the fact that, given the degree of concentration, large firms prefer to form RJVs with other large firms to maximise spillover internalisation. Röller et al. [1998] provide theoretical results pointing in that direction. Second, this may be an indication of significant fixed costs associated with RJV formation, such as the establishment of specific facilities (e.g. a new R\&D lab), or the administrative and negotiation efforts necessary to reach agreement with partners and/or sponsoring organisations. Third, large firms in an industry will have a strong incentive to participate in many RJVs in order to monitor innovative activity in their segment (a sophisticated form of 'technology watch'). ${ }^{9}$ Fourth, for inter-industry RJVs (that is, RJVs which involve technological complementarity), firms will be keen to cooperate with the largest — and more efficient_-firms in the

\footnotetext{
${ }^{8}$ The results are robust to the introduction of one only of $S P L$ and $P A T E F$ : each remains negative and significant when entered alone, and the remaining coefficients barely change.

${ }^{9}$ By definition, the largest firms - which are also the technology leaders-have most to lose from the emergence of new, technologically advanced, rivals.
} 
complementary industry. Last, the positive coefficient associated with this variable may reflect an exogenous preference for 'big business' on the part of the sponsoring organisation, or a process of regulatory capture. ${ }^{10}$

As for market share $(M S)$, this variable is not significant, except when firm size is excluded from the specification (see columns (1) and (3) of Table V). This simply reflects the fact that these two variables measure pretty much the same thing: a firm's absolute size versus its relative size. We opted to maintain firm size and drop market share for two reasons. First, $\log (F S)$ turned to be systematically more significant than $M S$ when these variables were entered on their own (and not in tandem). More importantly, absolute size not only reflects a firm's position relative to its competitors, but also indicates whether it is better placed to support the fixed outlays associated with the creation of an RJV.

The coefficients capturing past participations in Eureka or EU-FP projects (EXP-FP and EXP-EU) are significant at less than the $1 \%$ level in both cases. There are two non-exclusive explanations for this finding. First, it may reflect the fact that a large part of the fixed costs associated with RJV formation have to be paid only once. Thus, having already incurred these costs, firms' marginal cost of launching a new venture may very well be negligible. Second, the positive sign may be an indication that there is an important learning process in achieving successful cooperation. In addition, there is also the possibility that these variables capture the effect of unobserved determinants of RJV participation.

Table VI presents point estimates for the coefficients on the country dummies. These estimates suggest that firms originating in the larger EU countries (Germany, France, UK, Italy, and to a lesser extent, Spain) are less likely to participate in pan-European RJVs. This reflects the fact that large country firms find it easier to find RJV partners within their own borders. The other country dummy that is significantly negative is the Polish one. Apart from country size, the lower propensity of Polish firms to participate in pan-European RJVs probably results from the relative 'isolation' of the Polish economy during the time period studied in this paper. Three dummies are positive and 'almost' significant (Finland, Greece and Denmark), and all three relate to small countries, thus mirroring the effect identified above for the bigger economies.

Overall, the fit of the regressions is good, with a log-likelihood ratio that is significant well below the $1 \%$ level, irrespective of the specification. The pseudo- $R^{2}$ are also satisfactory, reaching 0.34 in the most complete specification.

The policy implications of these findings can be summarised as follows.

${ }^{10}$ As it is necessary expand resources (e.g. lobbying) to achieve effective capture, large firms are typically in a better position to achieve these ends. 
First, it emerges that competition authorities do well to monitor cooperative agreements in research activities, as those are found in more concentrated industries and mainly involve large firms. Secondly, the sign and significance of the 'past experience' variables might indicate that firms appear as satisfied with RJVs, and it might also reflect that there are strong fixed costs and learning effects associated with an RJV.

\section{REFERENCES}

Filer, R. K. and Hanousek, J., 2002, 'Data Watch: Research Data from Transition Economies', The Journal of Economic Perspectives, 16(1), pp. 225-240.

Kamien, M., Müller, E. and Zang, I., 1992, 'Research Joint Ventures and R\&D Cartels', The American Economic Review, 82, pp. 1293-1306.

Katsoulacos, Y. and Ulph, D, 1998, 'Endogenous Spillovers and the Performance of Research Joint Ventures', The Journal of Industrial Economics, 46, pp. 333-357.

Kogut, B., 1991, 'Joint Ventures and the Option to Expand and Acquire', Management Science, 37, pp. 19-33.

Levin, R., Klevorick, A., Nelson, R. and Winter, S., 1987, 'Appropriating the Returns from Industrial Research and Development', Brookings Papers on Economic Activity, 3, pp. 783-831.

Mansfield, E., 1985, 'How Rapidly Does New Industrial Technology Leak Out?', Journal of Industrial Economics, 34, pp. 217-223.

Moulton, B., 1990, 'An Illustration of a Pitfall in Estimating the Effects of Aggregate Variables on Micro Unit', Review of Economics and Statistics, 72, pp. 334-338.

Nelson, R., 1993, National Innovation Systems: A Comparative Analysis, (Oxford University Press).

Neven, D., Papandropoulos, P. and Seabright, P., 1988, Trawling for Minnows. European Competition Policy and Agreements Between Firms, (Centre for Economic Policy Research, London).

Petit, M. and Towlinski, B., 1999, 'R\&D Cooperation or Competition', European Economic Review, 43, pp. 185-208.

Röller, L.-H., Tombak, M. and Siebert, R., 1998, 'The Incentives to Form Research Joint Ventures: Theory and Evidence', Discussion Paper WZB, FS IV 98-15. 